\title{
Influence of Fines on the Compressibility of Surface Sands in Kuwait
}

\author{
Shaikha A. N. AlAbdulmuhsen \\ engshaikhaa@hotmail.com \\ University College London, London, UK
}

\begin{abstract}
Influence of fines on the strength and compressibility of compacted fill soil is very important in determining its behavior under applied loads. In Kuwait, fill soil is usually backfilled from excavated surface soils that consists of windblown dune sand with fines content usually varying from $5 \%$ to $15 \%$ with an average of $10 \%$. However, it exceeds the upper range at some sites. This sand is used as backfill in compacted layers around foundations and below ground slabs. This paper investigates the influence of fines on the compressibility of surface sands. Laboratory consolidation tests were carried out on two types of sand samples with different fines contents to determine the compressibility parameters that included the compression index $\left(\mathrm{C}_{\mathrm{c}}\right)$, the swell index $\left(\mathrm{C}_{\mathrm{s}}\right)$, and the coefficient of consolidation $\left(\mathrm{C}_{\mathrm{v}}\right)$. The influence of relative compaction on the compressibility parameters of both sands was also examined. Results indicated that the compression index $\left(\mathrm{C}_{\mathrm{c}}\right)$ values decreased from 0.082 to 0.016 for sands with $7.3 \%$, and from 0.089 to 0.016 for sands with $14.6 \%$ fines, when the relative compaction increased from 80 to $100 \%$. The swell index Cs also decreased with increasing relative compaction for both sands. Moreover, with increasing fines, the compressibility increased as demonstrated by the larger values of $\mathrm{Cc}$ at all degrees of relative compaction except at $100 \%$ and that the coefficient of consolidation $\mathrm{Cv}$ decreased with increasing fines, which means that as the fines increase the time required to achieve a certain degree of consolidation will also increase.
\end{abstract}

Keywords: Compressibility; Fines; Compression index; Swell index; Coefficient of consolidation

\section{INTRODUCTION}

Generally, natural sands consists of fines and sands in different proportions. The fines content affects the engineering properties of sands. The soil profile in Kuwait consists of a surface layer of windblown dune sand underlain by cemented sands (Ismael, 1985). It varies in thickness from 0 to $7 \mathrm{~m}$ and consists of fine or fine to medium sands with some fines (Ismael et al., 1987). The fines are calcareous and softer in nature. The percent of fines usually varies from $5 \%$ to $15 \%$ with an average of $10 \%$. However, it exceeds the upper range at some sites. This sand is used as backfill in compacted layers around foundations and below ground slabs. The influence of fines on the strength and compressibility of surface sands compacted to different relative compaction (Rc) is very important in determining its behavior under applied loads (Ismael, 2006). The fines may also affect the compressional characteristics of coarse-grained soils (Çabalar, 2008). Further, compressibility characteristics deliver essential information of soil behavior. There are only few studies that have reported on the behavior of granular sandy and/or 
clayey soil with different fines contents.

Kim et al. (2005) performed a series of triaxial compression tests on soil mixed with various silt contents, and the results showed that the critical state friction decreased with the increase in fine aggregate content. Phan et al. (2016) investigated the effects of fines content on the engineering properties of sand - fines mixtures based on laboratory tests. They reported that as the fines content increased, all parameters of deviator stress, volumetric strain, shear stress, internal friction angle, and cohesion increased. Moreover, as the fines content increased, soil type with constant void ratio also showed degradation in the cohesion, internal friction angle, and critical state in the consolidated undrained shear test.

In this study, laboratory consolidation tests were carried out on samples of sand with two different fines content to determine the compressibility parameters. These include the Compression Index $(\mathrm{Cc})$, the Swell Index (Cs), and the Coefficient of Consolidation $(\mathrm{Cv})$. Consolidation tests were performed on samples compacted to different relative compaction specified from the modified proctor compaction test. The influence of relative compaction on the compressibility parameters of both sands was also examined.

\section{METHODOLOGY}

The natural sand used in the tests was collected from the surface of a selected test site in AI-Rai area in Kuwait city, where the fines content is almost $15 \%$. Bulk soil samples collected from excavated test pits were taken to the laboratory at Kuwait University for analysis and testing. The basic properties of the remolded soil sample were determined by conducting sieve analysis, consistency tests and compaction tests in the laboratory. Sieve analysis indicated that the percentage of fines in the soil was $14.63 \%$, which is approximately the maximum value of fines usually encountered for surface sand in Kuwait city (Ismael et a1., 1986). The fines are calcareous and softer in nature. Another soil sample was prepared by washing some part of original soil through sieve \# 200, and then adding the isolated fines based on weight calculations, so as to make the percentage of fines in the soil to be $7.3 \%$ (50\% of 14.63). For example, for every $92.7 \mathrm{~kg}$ of soil particles that remain in sieve \# 200,7.3 kg of fines were added. Figure 1 shows the grain size distribution for sand with $14.63 \%$ fines and sand with $7.3 \%$ fines.

After the sieve analysis tests, samples from both sets of soils were tested to determine the Atterberg limits (liquid and plastic limit), specific gravity, optimum water content and maximum dry density. The liquid limit and plastic limit for the sand with $14.63 \%$ fines was found to be 23 and 18, respectively. The sand with $7.3 \%$ fines is considered as non-plastic. According to the Unified Soil Classification System (ASTM 0-2487), the soil with $14.63 \%$ fines is classified as silty clayey sand (SC-SM), and the soil with $7.3 \%$ fines is classified as poorly graded sand with silt (SP-SM). In addition, the specific gravity for the sand with $14.63 \%$ fines was 2.61 and for the sand with $7.3 \%$ fines was 2.645 .

The Modified Proctor Compaction test (ASTM D-1557) was conducted on samples of both sets of soils to determine the max dry density $\left(\gamma_{\mathrm{d} \max }\right)$ and optimum water content $\left(w_{\text {opt }}\right)$. In order to determine the consolidation parameters, five one-dimensional consolidation tests were conducted on soil samples with different degrees of relative compaction, for each set of soils. The laboratory consolidation tests were carried out 
according to ASTM D-243, on the compacted soil samples with $14.63 \%$ fines at $80 \%$, $85 \%, 90 \%, 95 \%$ and $100 \%$ relative compaction at moisture contents corresponding to the wet side of the optimum water content. These tests were repeated on samples with $7.3 \%$ fines.

\section{RESULTS AND DISCUSSION}

Figure 2 shows the compaction curves for sands with $14.63 \%$ and $7.3 \%$ fines. For the sand with $14.63 \%$ fines, the maximum dry unit weight was found to be $2033 \mathrm{~kg} / \mathrm{m}^{3}$ and the optimum water content was $9.4 \%$. The corresponding values for the sand with $7.3 \%$ fines were $1954 \mathrm{~kg} / \mathrm{m}^{3}$ and $9.8 \%$, respectively.

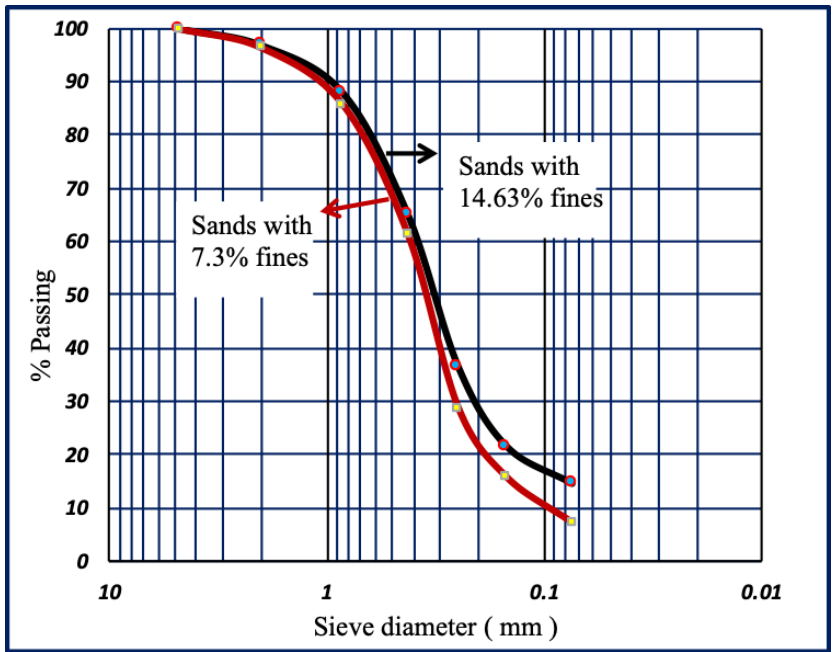

Figure 1: Grain Size Distribution curves for the test samples

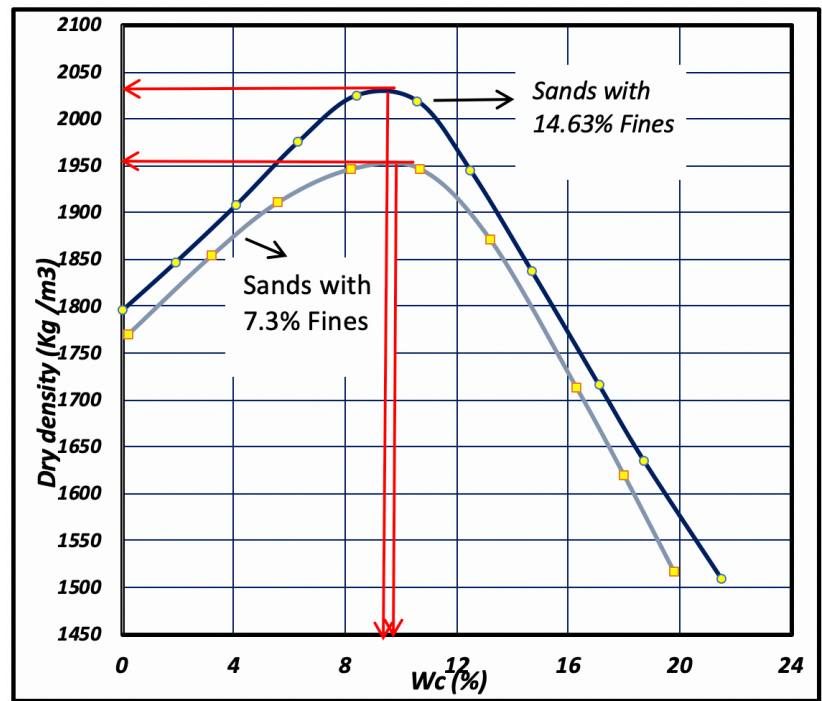

Figure 2: Compaction curves for the soil samples 
Table 1 shows a summary of the consolidation test results and Table 2 shows the variation of the coefficient of consolidation with the applied pressure increment for the different relative compaction values. Figure 3 shows comparison between the Compression Index $\left(\mathrm{C}_{\mathrm{C}}\right)$ and Swelling Index $\left(\mathrm{C}_{\mathrm{S}}\right)$ with increasing relative compaction. The average Coefficient of Consolidation $\left(\mathrm{C}_{\mathrm{v}}\right)$ values with respect to relative compaction for the soils with $7.3 \%$ and $14.6 \%$ fines, are plotted in Figure 4. Figures 5 and 6 show the e- $\log \sigma^{\prime}$ curves at different relative compaction for sands with $7.3 \%$ fines and $14.6 \%$ fines, respectively.

Table 1: Summary of the consolidation test results

\begin{tabular}{|c|c|c|c|c|c|c|c|c|c|c|c|c|}
\hline \multirow{2}{*}{ 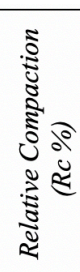 } & \multicolumn{2}{|c|}{$\begin{array}{c}\text { Water Content } \\
\text { Wc (\%) }\end{array}$} & \multicolumn{2}{|c|}{$\begin{array}{l}\text { Initial Void } \\
\text { Ratio }\left(\mathrm{e}_{0}\right)\end{array}$} & \multicolumn{2}{|c|}{$\begin{array}{c}\text { Dry Density } \\
\gamma_{\mathrm{d}-\max }\left(\mathrm{kg} / \mathrm{m}^{3}\right)\end{array}$} & \multicolumn{2}{|c|}{$\begin{array}{l}\text { Compression } \\
\text { Index } \\
\text { (Cc) }\end{array}$} & \multicolumn{2}{|c|}{$\begin{array}{r}\text { Swelling Index } \\
\text { (Cs) }\end{array}$} & \multicolumn{2}{|c|}{$\begin{array}{c}\mathrm{Avg} \cdot \mathrm{Cv} \\
\left(\mathrm{mm}^{2} / \mathrm{min}\right)\end{array}$} \\
\hline & $\begin{array}{l}\text { Sands } \\
\text { with } \\
7.3 \% \\
\text { fines }\end{array}$ & $\begin{array}{l}\text { Sands } \\
\text { with } \\
14.6 \% \\
\text { fines }\end{array}$ & $\begin{array}{l}\text { Inds } \\
\text { ith } \\
3 \% \\
\text { es }\end{array}$ & $\begin{array}{l}\text { Sands } \\
\text { with } \\
14.6 \%\end{array}$ & $\begin{array}{l}\text { nds } \\
\text { th } \\
3 \%\end{array}$ & $\begin{array}{l}\text { ds } \\
\mathrm{h} \\
6 \% \\
\mathrm{~s}\end{array}$ & $\begin{array}{l}\text { inds } \\
\text { ith } \\
3 \% \\
\text { ees }\end{array}$ & & $\begin{array}{l}\text { nds } \\
\text { th } \\
\% \\
\text { es }\end{array}$ & & $\begin{array}{l}\text { Sands } \\
\text { with } \\
7.3 \% \\
\text { fines }\end{array}$ & $\begin{array}{l}\text { Sands } \\
\text { with } \\
14.6 \% \\
\text { fines }\end{array}$ \\
\hline 80 & 19 & .85 & 702 & 542 & 63 & 626.4 & 082 & 89 & 0000 & & 570 & 3 \\
\hline 85 & & 16.75 & 0.60 & & 660 & 1728 & .04 & .068 & .0 & & 679 & 672. \\
\hline 90 & & & 0.5 & 42 & 158 & 1829.7 & 0 & 0.035 & 0 & & 685 & 67. \\
\hline 95 & & 2.7 & 0.4 & & 1000. & 1931.4 & 0.018 & 0023 & 0.00 r & & 692.0 & 690.5 \\
\hline 100 & 9.8 & 9.4 & .501 & 0.212 & 1934.0 & 2035.0 & 0.016 & 0.01 & 0.00 & 0.0 & 694. & 695 \\
\hline
\end{tabular}

Table 2: Variation of coefficient of consolidation with applied pressure

\begin{tabular}{|c|c|c|c|c|c|c|c|c|c|c|}
\hline Rc \% & & $80 \%$ & & $85 \%$ & & $90 \%$ & & $95 \%$ & & $100 \%$ \\
\hline $\begin{array}{l}\text { Pressure } \\
\text { (kpa) }\end{array}$ & $\begin{array}{l}\text { Sands } \\
\text { with } \\
7.3 \% \\
\text { fines }\end{array}$ & $\begin{array}{l}\text { Sands } \\
\text { with } \\
14.6 \% \\
\text { fines }\end{array}$ & $\begin{array}{l}\text { Sands } \\
\text { with } \\
7.3 \% \\
\text { fines }\end{array}$ & $\begin{array}{l}\text { Sands } \\
\text { with } \\
14.6 \% \\
\text { fines }\end{array}$ & $\begin{array}{l}\text { Sands } \\
\text { with } \\
7.3 \% \\
\text { fines }\end{array}$ & $\begin{array}{l}\text { Sands } \\
\text { with } \\
14.6 \% \\
\text { fines }\end{array}$ & $\begin{array}{l}\text { Sands } \\
\text { with } \\
7.3 \% \\
\text { fines }\end{array}$ & $\begin{array}{l}\text { Sands } \\
\text { with } \\
14.6 \% \\
\text { fines }\end{array}$ & $\begin{array}{l}\text { Sands } \\
\text { with } \\
7.3 \% \\
\text { fines }\end{array}$ & $\begin{array}{l}\text { Sands } \\
\text { with } \\
14.6 \% \\
\text { fines }\end{array}$ \\
\hline 6 & 700.4 & 700 & 699.4 & 700.5 & 701.6 & 688 & 701 & 546.5 & 702.44 & 703 \\
\hline 12 & 697.3 & 695.6 & 695.5 & 696.6 & 699.4 & 686 & 699 & 688.2 & 701.5 & 702 \\
\hline 25 & 690 & 682.8 & 689.5 & 689.1 & 696 & 683 & 696.4 & 731.2 & 699.4 & 700 \\
\hline 50 & 678 & 661.6 & 682.3 & 678.9 & 690 & 678 & 652.8 & 737.4 & 696.2 & 697 \\
\hline 100 & 662 & 640 & 673.9 & 665 & 686.9 & 671.5 & 732 & 687.3 & 692.3 & 693 \\
\hline 200 & 644 & 656.7 & 664.5 & 648 & 680.6 & 663 & 684 & 680.5 & 687.8 & 688 \\
\hline 400 & 623.4 & 634.6 & 652.2 & 629.7 & 674.4 & 652.5 & 678.5 & 762.7 & 682.7 & 683 \\
\hline
\end{tabular}



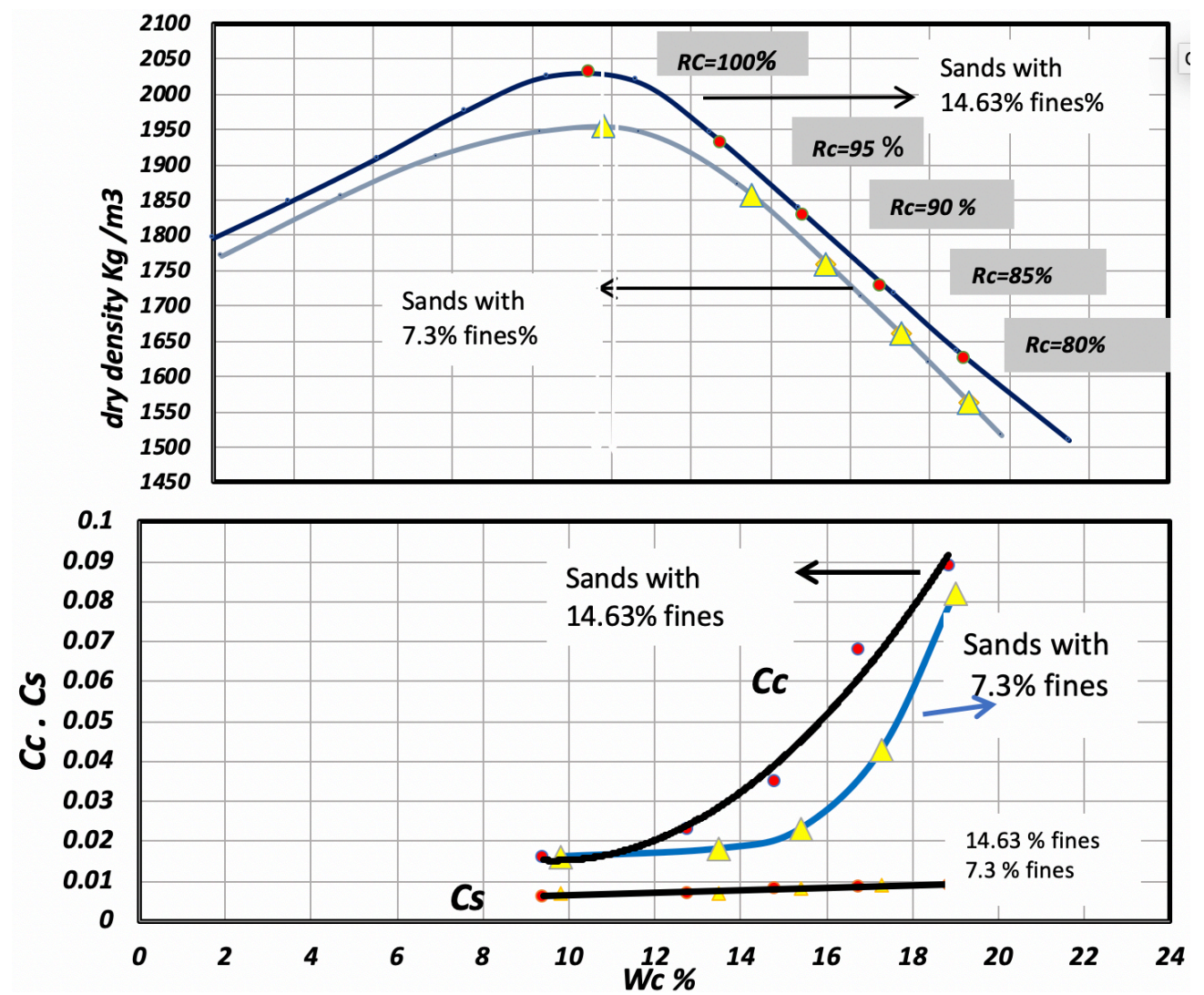

Figure 3: Comparison between the Compression Index (Cc) and Swelling Index (Cs) values

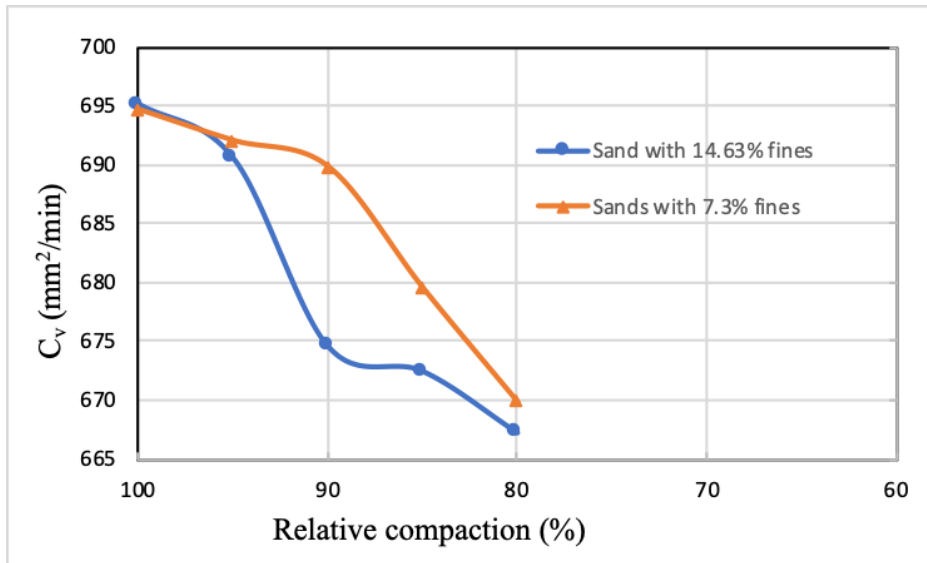

Figure 4: Variation of Coefficient of Consolidation $\left(\mathrm{C}_{\mathrm{v}}\right)$ with the relative compaction 


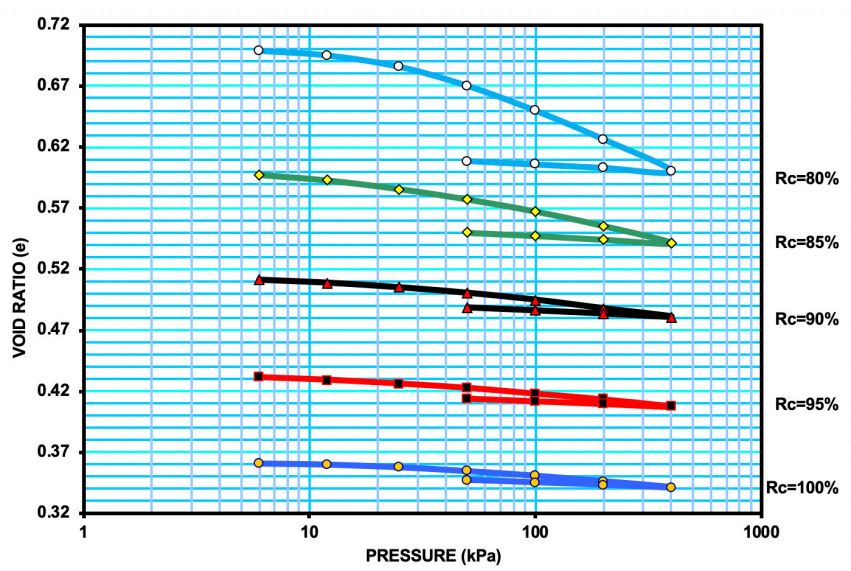

Figure 5: e- $\log \sigma^{\prime}$ curves at different relative compaction for sand with $7.3 \%$ fines

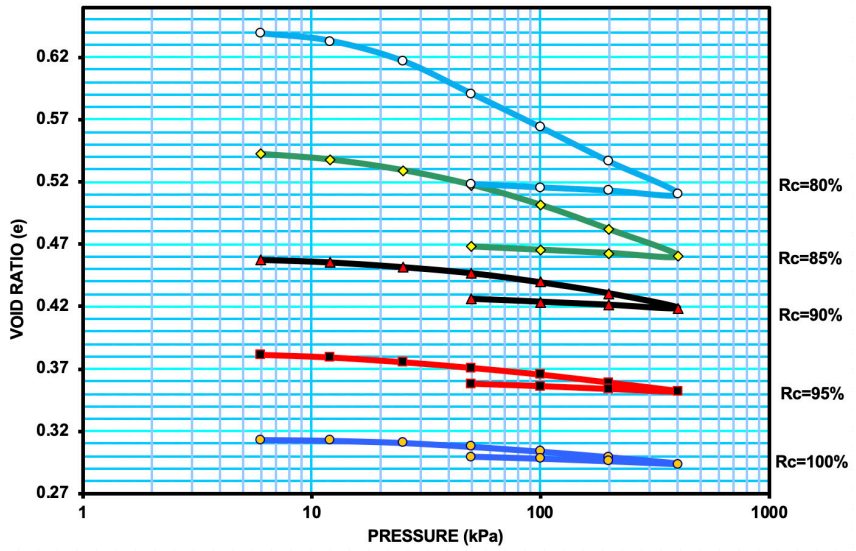

Figure 6: e- $\log \sigma^{\prime}$ curves at different relative compaction for sand with $14.63 \%$ fines

As represented in Table1, for both sets of soil samples (with $14.63 \%$ fines and $7.3 \%$ fines) the Compression Index (Cc) decreased sharply as the relative compaction increased from $80 \%$ to $90 \%$, and decreased at a slower rate as the relative compaction increased from $90 \%$ to $100 \%$. This decrease in compression index values indicates that the compressibility decreased and stiffness increased as the relative compaction increased. The ratio of $\mathrm{C}_{\mathrm{c}}$ at $90 \%$ to $\mathrm{Cc}$ at $80 \%$ is 0.28 and the ratio of $\mathrm{Cc}$ at $100 \%$ to $\mathrm{Cc}$ at $90 \%$ is 0.69 for the test soil with $7.3 \%$ fines. Similar observations were made for the samples with $14.6 \%$ fines. The Swelling Index (Cs) decreased slightly as the relative compaction increased as shown in Table 1 and Figure 4.

A summary of the pre-consolidation pressure values $\sigma_{c}$ as determined at different relative compaction values is given in Table 3 . From Table 3 it is clear that $\sigma_{\mathrm{c}}$ remained nearly the same except at $80 \%$ relative compaction for the sand with $14.6 \%$ fines where a significant decrease occurred. 
Table 3: Variation of pre-consolidation pressure with relative compaction

\begin{tabular}{|c|c|c|}
\hline \multirow{2}{*}{$\begin{array}{c}\text { Relative } \\
\text { Compaction } \\
\text { (Rc \%) }\end{array}$} & \multicolumn{2}{|c|}{ Pre-Consolidation Pressure, $\sigma_{\mathrm{c}}{ }^{\prime}(\mathrm{kPa})$} \\
\hline & $\begin{array}{l}\text { Sands with } \\
7.3 \% \text { fines } \\
\end{array}$ & $\begin{array}{l}\text { Sands with } 14.6 \\
\% \text { fines }\end{array}$ \\
\hline $80 \%$ & 40 & 27 \\
\hline $85 \%$ & 45 & 48 \\
\hline $90 \%$ & 42 & 50 \\
\hline $95 \%$ & 43 & 43 \\
\hline $100 \%$ & 38 & 45 \\
\hline
\end{tabular}

The above results show the important effect of fines on compressibility. As the fines increase the compression index increases at all values of relative compaction except at the $100 \%$ value. A possible explanation is that the decrease with low void ratio makes the effect of increased fines within the range of this project insignificant. Increased compressibility leads to larger settlement under the applied loads as the settlement is directly proportional to $\mathrm{C}_{\mathrm{c}}$.

Looking at the coefficient of consolidation $\mathrm{C}_{\mathrm{v}}$, it is evident from Figure 5 that $\mathrm{C}_{\mathrm{v}}$ is lower with increased fines content at all relative compaction except $100 \%$. It is known that for a given degree of consolidation, the time is inversely proportional to the coefficient of consolidation. Thus, it is clear that with lower values of $\mathrm{C}_{\mathrm{v}}$ with higher fines, the time required to achieve a given degree of consolidation will be longer due to the lower permeability and the plastic nature of the soil containing larger fines content. As indicated in Figures $6 \& 7$, the void ratio also decreased with increase in relative compaction.

\section{CONCLUSION AND RECOMMENDATION}

A laboratory-testing program consisting of compaction and consolidation tests was carried out on two sets of sands with fines content of $14.7 \%$ and $7.3 \%$. The following conclusion were made based on the laboratory test results:

i. For both sands, compressibility decreased as the relative compaction increased from $80 \%$ to $100 \%$. The Compression Index Cc and the Swell Index Cs decreased with increasing relative compaction.

ii. The Compression Index (Cc) values decreased from 0.082 to 0.016 for sands with $7.3 \%$, and from 0.089 to 0.016 for sands with $14.6 \%$ fines, when the relative compaction increased from 80 to $100 \%$.

iii. The average Coefficient of Consolidation (Cv) increased from 670 to $695 \mathrm{~mm}^{2} / \mathrm{min}$ for both types of sands with increasing Relative Compaction (Rc).

iv. With increasing fines, the compressibility increased as demonstrated by the larger values of $\mathrm{C}_{\mathrm{c}}$ at all degrees of relative compaction except at $100 \%$.

v. The Coefficient of Consolidation $\mathrm{C}_{\mathrm{v}}$ decreased with increasing fines. This indicates that as the fines increase the time required to achieve a certain degree of consolidation will also increase.

It is recommended to carry out the same tests on soils with fines content up to $30 \%$ to confirm the findings of this study. 


\section{REFERENCES}

Çabalar, A. F. (2008). Effect of fines content on the behavior of mixed samples of a sand. The Electronic Journal of Geotechnical Engineering, Volume 13D. Available on line at: http:// ejge.com/2008/Ppr0835.pdf.

Ismael, N. F. (1985). Allowable pressure from loading tests on Kuwaiti soils. Canadian Geotechnical Journal, 22 (2): 151-157.

Ismael, N. F. (2006). Influence of fines on the properties of arid climate sand deposits, proceedings of the $4^{\text {th }}$ international conference on unsaturated soils, Conference. Arizona, USA. April 2-6.

Ismael, N. F., Al-Khalidi, O. \& Mollah, M. A. (1987). Saturation effects on calcareous desert sands. Transportation Research Record, 1089 pp.

Ismael, N. F., Jeragh, A. M., Mollah, M. A. \& Al-Khalidi, O. (1986). A study of the properties of surface soils in Kuwait, Journal of the Southeast Asian Geotechnical society, Bangkok, Thailand, 17(1): 67-87.

Kim, D., Sagong, M. \& Lee, Y. (2005). Effects of fine aggregate content on the mechanical properties of the compacted decomposed granitic soils. Construction and Building Materials, 19(3):189-196.

Phan, V. T. A., Hsiao, D. H. \& Nguyen, T. L. (2016). Effects of fines contents on engineering properties of sand-fines mixtures. Sustainable Development of Civil, Urban \& Transportation Engineering Conference. Procedia Engineering, 142:212-219. Elsevier Ltd. 